Section Editor

Mitchell S.V. Elkind, MD, MS

Adam R. Moeck, BS

Paola Pergami, MD, PhD

Correspondence to

Dr. Pergami:

ppergami@hsc.wvu.edu
Teaching NeuroImages:

\section{A pediatric patient with headache and neck stiffness}

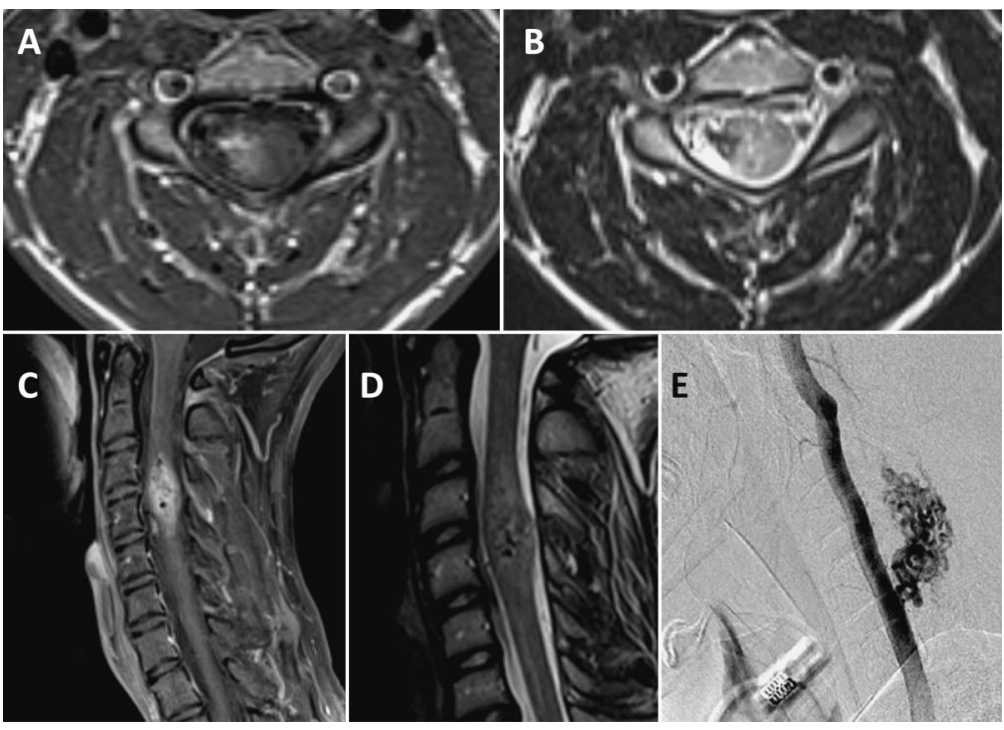

Cervical spine MRI demonstrates a glomus type intramedullary arteriovenous malformation. Multiple flow voids at the C3-C4 level involve the right hemicord. Axial (A) and sagittal (C) T1-weighted images, postgadolinium; axial (B) and sagittal (D) T2-weighted images. Angiography (E) shows compact nidus with single arterial feeder from the right vertebral artery.
A 14-year-old right-handed boy presented with sudden onset of severe headache and neck stiffness. Physical examination showed arm asymmetry with smaller size and muscle bulk (present since childhood) and increased deep tendon reflexes on the right, but normal strength. Brain CT and lumbar puncture ruled out subarachnoid hemorrhage or infection. MRI and angiography (figure) identified an unruptured type III spinal arteriovenous malformation at the C3-C4 level, supplied by the right vertebral artery. ${ }^{1}$ Subtle physical examination findings can indicate underlying pathology and should not be overlooked in the proper context. Vascular studies should be considered for severe headache with negative initial workup. ${ }^{2}$

\section{AUTHOR CONTRIBUTIONS}

Adam Moeck: drafting/revising the manuscript, accepts responsibility for conduct of research and final approval. Paola Pergami: drafting/revising the manuscript, study concept or design, analysis or interpretation of data, accepts responsibility for conduct of research and final approval, study supervision.

\section{STUDY FUNDING}

No targeted funding reported.

\section{DISCLOSURE}

The authors report no disclosures relevant to the manuscript. Go to Neurology.org for full disclosures.

\section{REFERENCES}

1. Spetzler RF, Detwiler PW, Riina HA, Porter RW. Modified classification of spinal cord vascular lesions. J Neurosurg 2002;96:145-156.

2. Mortimer AM, Bradley MD, Stoodley NG, Renowden SA. Thunderclap headache: diagnostic considerations and neuroimaging features. Clin Radiol 2013;68: 101-113. 


\section{Neurology}

Teaching NeuroImages: A pediatric patient with headache and neck stiffness

Adam R. Moeck and Paola Pergami

Neurology 2013;81;e101

DOI 10.1212/WNL.0b013e3182a55f5b

This information is current as of September 23, 2013

\section{Updated Information \& Services \\ Supplementary Material \\ References \\ Subspecialty Collections}

Permissions \& Licensing

Reprints including high resolution figures, can be found at: http://n.neurology.org/content/81/13/e101.full

Supplementary material can be found at: http://n.neurology.org/content/supp1/2013/09/21/81.13.e101.DC1

This article cites 2 articles, 0 of which you can access for free at: http://n.neurology.org/content/81/13/e101.full\#ref-list-1

This article, along with others on similar topics, appears in the following collection(s):

\section{All Pediatric}

http://n.neurology.org/cgi/collection/all_pediatric

All Spinal Cord

http://n.neurology.org/cgi/collection/all_spinal_cord

Arteriovenous malformation

http://n.neurology.org/cgi/collection/arteriovenous_malformation Pediatric headache

http://n.neurology.org/cgi/collection/pediatric_headache

Information about reproducing this article in parts (figures,tables) or in its entirety can be found online at:

http://www.neurology.org/about/about_the_journal\#permissions

Information about ordering reprints can be found online:

http://n.neurology.org/subscribers/advertise

Neurology ${ }^{\circledR}$ is the official journal of the American Academy of Neurology. Published continuously since 1951, it is now a weekly with 48 issues per year. Copyright (C 2013 American Academy of Neurology. All rights reserved. Print ISSN: 0028-3878. Online ISSN: 1526-632X.

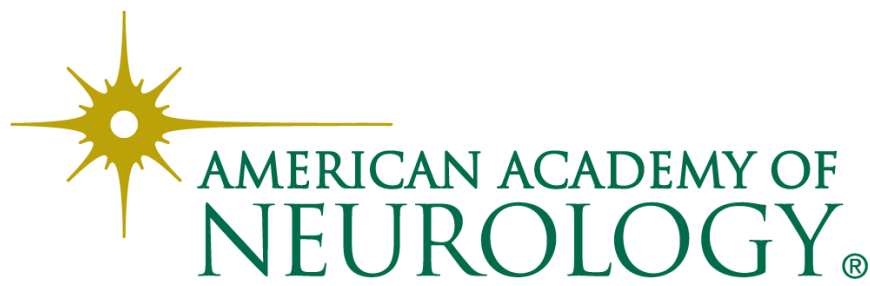

